\title{
Optimum dietary crude protein requirement for juvenile cachama Piaractus brachypomus
}

\author{
Exigência ótima de proteína bruta para juvenis de pirapitinga, Piaractus brachypomus
}

\author{
Wálter Vásquez-Torres $^{I^{*}}$ Manoel Pereira-Filho ${ }^{\mathrm{I} \dagger}$ Jose Alfredo Arias-Castellanos $^{\mathrm{I}}$
}

\begin{abstract}
A growth experiment was conducted to determine the optimal dietary protein requirement for juvenile cachama, Piaractus brachypomus. Six semi-purified isoenergetic experimental diets using casein and gelatin as protein sources were formulated to contain graded levels of protein $(16,20$, 24, 28, 32 and 36\%). Fish initially averaging $15.52 \pm 0.33 \mathrm{~g}$ (mean $\pm S D)$ were randomly distributed into the tanks (500L) as groups of 20 fish and fed to apparent satiation twice daily for 60 days. The results showed that feed consumption, feed conversion ratio, fish weight gain, specific growth rate, protein efficiency ratio and protein productive value were affected by dietary protein level $(P<0.05)$. No significant differences were observed in proximal composition of carcass $(P<0.05)$ in response to dietary protein. Analysis of dietary protein level $x$ $W G$ with a second order polynomial regression suggested a requirement of $31.6 \%$ CP for optimum growth.
\end{abstract}

Key words: tropical fish, protein requirements, growth performance, feed utilization, whole-body composition.

\section{RESUMO}

$O$ presente experimento foi realizado para determinar o requerimento ótimo de proteína em dietas para juvenis de pirapitinga, Piaractus brachypomus. Foram formuladas seis dietas experimentais semi-purificadas, isoenergéticas e com diferentes níveis de proteína (16, 20, 24, 28, 32 e $36 \%$ de PB) usando caseína e gelatina como fontes de

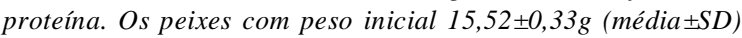
foram distribuídos aleatoriamente em grupos de 20 animais por tanque; foram alimentados durante 60 dias, duas vezes/ dia até aparente saciedade. Os resultados mostraram que o consumo de alimento, taxa de conversão de alimento, ganho de peso, taxa de crescimento específico, taxa de eficiência de proteína e valores produtivos da proteína e da energia foram significativamente afetados pelos níveis de proteína das dietas $(P<0,05)$. Não foram observadas diferenças significativas na composição proximal da carcaça $(P<0,05)$ entre tratamentos. A análise do ganho de peso em função dos níveis de proteína da dieta, realizada utilizando regressão polinomial de segundo grau, deu um requerimento de $31,6 \%$ de proteína para ótimo crescimento de juvenis de pirapitinga.

Palavras-chave: peixe tropical, níveis de proteína, desempenho de crescimento, utilização de alimento, composição corporal.

\section{INTRODUCTION}

A protein is the main organic component of the fish tissues and at the same time, the most abundant and costly in commercial feeds. In addition to being used for growth and repair of tissues, protein is also used extensively for providing energy in routine metabolism by fish (GUILLAUME et al., 2004). It is therefore, an essential nutrient for both maintenance and growth (DE SILVA \& ANDERSON, 1995). Determining the minimum protein level in the diet which allows maximum growth for each species is one of the first challenges nutrition research which enable the development of highly efficient and low cost commercial feeds. In general, fish require relatively high levels of

IPrograma de Pós-graduação em Aquicultura, Instituto de Aquicultura (IALL), Universidad de los Llanos, Km 12, via Puerto López, Vereda Barcelona, Villavicencio, Colombia. E-mail: wvasquezt@unal.edu.co. *Autor para correspondência.

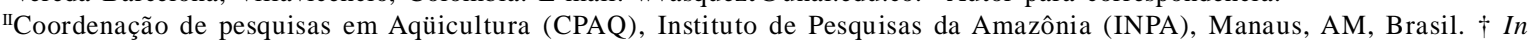
memoriam. 
protein in their diet compared to other terrestrial warmblooded animals (NRC, 1993). Demands among the different group species are not very different and depend upon factors such as: feeding habits, water temperature (cold or tropical), environment (marine or freshwater) and stage of physiological development. According to reports by NRC (1993), for maximum growth the majority of fish species on commercial farms in the world require diets with protein level that vary between 31 and 56\%. Most of these values were estimated from dose-response curves, yielding the minimum amount of dietary protein which resulted in maximum growth (WILSON, 2002). Information also shows that such protein needs decrease as fish weight increases. Protein ingested by fish is used in maintenance and growth, but when they are overfed only one part of this protein is effectively used for synthesis of new proteins and the remaining is metabolized to produce energy (WILSON, 2002), with an unavoidable increase of nitrogen excretion to the aquatic system (OISHI et al., 2010; WEBB \& GATLIN III, 2003). Consequently, when fish are fed with optimal dietary protein levels they retain a proportionally higher amount of protein in the body (growth), decreasing production costs and pollution (THOMAN et al., 1999).
Neotropical and omnivorous freshwater species such as Piaractus and Colossoma (Characidae, Serrasalminae) (ARAUJO-LIMA, 1997), are very important for commercial aquaculture industry in South America and other Central American countries (aproxim. 90.000MT year-1 ${ }^{-1}$ IBAMA, 2009; MADR, 2009). However, there is little information on dietary protein requirements for growth in these species. Thus, it is important that studies on its nutrition should be carried out to develop cost-effective and nutritionally balanced feed formulation for these fish. Consequently, the present study was designed to investigate the dietary protein requirement and evaluate the effects of dietary protein level on growth performance for juveniles cachama, Piaractus brachypomus.

\section{MATERIALS AND METHODS}

Six isoenergetic diets with 16, 20, 24, 28, 32, and $36 \%$ of CP were formulated. Protein levels were adjusted as in VÁSQUEZ-TORRES et al. (2002). Dextrin and oils ( $50 \%$ oil corn $+50 \%$ oil fish) proportions were adjusted to maintain diets isoenergetic with approximately $3080 \mathrm{kcal} \mathrm{DE} \mathrm{kg}^{-1}$. Concentration of other ingredients was the same for all diets (Table 1). Three

Table 1 - Ingredients and proximate composition of experimental diets.

\begin{tabular}{|c|c|c|c|c|c|c|}
\hline \multirow{2}{*}{ Ingredients (\%) } & \multicolumn{6}{|c|}{ 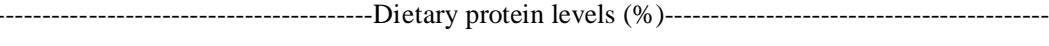 } \\
\hline & 16 & 20 & 24 & 28 & 32 & 36 \\
\hline Casein $^{1}$ & 17.90 & 22.40 & 26.90 & 31.40 & 35.90 & 40.30 \\
\hline Gelatin $^{2}$ & 2.20 & 2.70 & 3.20 & 3.80 & 4.30 & 4.90 \\
\hline Dextrin & 37.90 & 34.50 & 31.10 & 27.60 & 24.20 & 20.80 \\
\hline Fish oil + Corn oil & 13.0 & 11.4 & 9.80 & 8.20 & 6.60 & 5.00 \\
\hline Others ingredients ${ }^{3}$ & 29.0 & 29.0 & 29.0 & 29.0 & 29.0 & 29.0 \\
\hline Dry matter (\%) & 62.60 & $\begin{array}{c}\text { analysi } \\
57.30\end{array}$ & $\begin{array}{c}\text { ry matte } \\
59.50\end{array}$ & 57.90 & 56.90 & 57.80 \\
\hline Crude protein & 14.80 & 20.80 & 24.30 & 28.20 & 32.60 & 37.40 \\
\hline Crude lipids & 12.40 & 10.70 & 9.10 & 8.90 & 5.70 & 5.40 \\
\hline Ash & 3.90 & 4.30 & 4.30 & 4.90 & 4.70 & 4.60 \\
\hline Gross Energy $\left(\mathrm{kcal} \mathrm{kg}^{-1}\right)^{4}$ & 5527 & 5452 & 5511 & 5482 & 5421 & 5431 \\
\hline Estimated DE $\left(\mathrm{kcal} \mathrm{kg}^{-1}\right)^{5}$ & 3116 & 3100 & 3085 & 3071 & 3056 & 3041 \\
\hline
\end{tabular}

${ }^{1}$ Casein: DM 93.0\%, CP 86.42\%, Lipid 2.29\%, Ash 3.66\%, EAA ( $\left.\mathrm{g} \mathrm{kg}^{-1} \mathrm{CP}\right)$ : Met 29.1, Lys 80.6, Thr 41.4, Arg 34.3, I-leu 50.2, Leu 93.4, Val 65.4, His 31.0, Phe 50.2.

${ }^{2}$ Gelatin: DM 91.0\%, CP 94.02\%; EAA ( $\mathrm{g} \mathrm{kg}^{-1}$ CP): Met 9.2, Lys 38.1, Thr 18.7, Arg 82.5, I-leu 15.2, Leu 30.2, Val 23.7, His 7.2, Phe 20.7. ${ }^{3}$ Others ingredients: Vitamin mixture Rovimix $0.1 \%$ Lab. Roche S.A: Vit. A $8 \times 10^{6} \mathrm{UI}$; Vit. $\mathrm{D}_{3} 1.8 \times 10^{6} \mathrm{UI}$, Vit. E 66.66g, Vit. B $6.66 \mathrm{~g}$, Vit. $\mathrm{B}_{2}$ 13.33g, Vit. $\mathrm{B}_{6} 6.66 \mathrm{~g}$, Panthotenic acid 33.33g, Biotin 533.3mg, Folic acid 2.66g, Ascorbic acid 400.0g, Nicotinic acid 100.0g, Vit. B 12 20.0mg, Vit. $\mathrm{K}_{3} 6.66 \mathrm{~g}$, filer csp. 1.0kg,Vitamin C (StayC-35) 0.03\% Lab. Roche S.A.

Mineral mixture: microminerais 0.05\%: $\mathrm{Mg} \mathrm{10}$, Zn 160, Fe 40, Cu 10, I 5.0, Se 0.5, Co 0.1, filer csp. 1.0kg; macro-minerals: 4.02\%: $\mathrm{Ca}\left(\mathrm{H}_{2} \mathrm{PO}_{4}\right) 136 \mathrm{~g} ; \mathrm{Ca}$ Lactate $348.5 \mathrm{~g} ; 2 \mathrm{MgSO}_{4} .7 \mathrm{H}_{2} \mathrm{O}, 132 \mathrm{~g} ; \mathrm{KH}_{2} \mathrm{PO}_{4} 240 \mathrm{~g} ; \mathrm{NaCl} 45 \mathrm{~g} ; \mathrm{AlCl}_{3} 0.15 \mathrm{~g}, \mathrm{CMC} 98.35 \mathrm{~g}$.

Cellulose 18.0\%; CMC 6.8\%.

${ }^{4}$ Gross Energy: measured through a ballistic bomb calorimeter (PARR 121 EA. USA)

${ }^{5}$ Calculated using DE (kcal kg-1) values for catfish (NRC. 1993): Casein: 4400, gelatin: 4700, dextrin: 2920, oils 8600.

Ciência Rural, v.41, n.12, dez, 2011. 
hundred and sixty fish $\boldsymbol{P}$. brachypomus juveniles obtained by induced spawning at the Instituto de Acuicultura de la Universidad de los Llanos were acclimatized to the experimental conditions for two weeks prior to the experiment. Fish initially averaging $15.52 \pm 0.3 \mathrm{~g}$ were distributed into the $500 \mathrm{~L}$ tanks in groups of 20 fishes. The six experimental diets were randomly assigned to the tanks (six treatments in triplicate). Juveniles were fed twice daily (at 8:00 and 15:00 hours) until apparent satiety for 60 days, registering daily food intake for each experimental unit. Each tank was adjusted to maintain a continuous flow of water at a rate of $2 \mathrm{~L} \mathrm{~min}{ }^{-1}$ and constant aeration to maintain dissolved oxygen near $60 \%$ saturation. Water was continuously recycled through a unit that included a mechanical filter to remove suspended particles and a series of four bio-filters for nitrification (removal of ammonia and nitrite). Water quality parameters were monitored three times a week between 10:00 and 11:00h. During the experiment period, temperature was $26 \pm 1.2^{\circ} \mathrm{C}$, pH 7.3 \pm 0.2 , hardness $40-80 \mathrm{mg} \mathrm{L}^{-1} \mathrm{CaCO}_{3}$, ammonia nitrogen was lower than $0.02 \mathrm{mg} \mathrm{L}^{-1}$ and dissolved oxygen was not less than $4.7 \mathrm{mg} \mathrm{L}^{-1}$. At the end of the growth trial, fish were starved for $24 \mathrm{~h}$ and then weighed. A sample of 20 fish from the initial group and 10 of each replicate at the end of the experiment were sacrificed for carcass proximate analysis. Crude protein, crude lipid, moisture and ash in diets and fish whole body composition were performed in triplicate by the standard methods. Water quality parameters were measured using a multiparameter probe YSI 556 (YSI Incorporated, Yellow Springs, OH USA). At the end of the experiment, after a $24 \mathrm{~h}$ fasting period, all fish were weighted individually. Criteria to evaluate dietary effects were: Weight Gain $(\mathrm{WG})=\mathrm{W}_{\mathrm{f}}(\mathrm{g})-\mathrm{W}_{\mathrm{i}}(\mathrm{g})$; Specific Growth Rate $(S G R)=\left(\ln \mathrm{W}_{\mathrm{f}}-\ln \mathrm{W}_{\mathrm{i}}\right) \times 100 / \mathrm{t}$; Dry Feed Intake g DM kg-1 days ${ }^{-1}(\mathrm{DFI})=100 \mathrm{x} \mathrm{FI} /\left[\left(\mathrm{W}_{\mathrm{i}}\right.\right.$ $\left.+\mathrm{W}_{\mathrm{f}}\right) / 2 \mathrm{xt}$; Feed Conversion Ratio $(\mathrm{FCR})=\mathrm{FI}(\mathrm{g}) /$ WG; Protein Efficiency Ratio (PER) = WG / CPI; Protein Productive Value $(\mathrm{PPV})=100\left(\mathrm{CP}_{\mathrm{f}}-\mathrm{CP}_{\mathrm{i}}\right) / \mathrm{CPI}$; Energy Productive Value $(\mathrm{EPV})=100\left(\mathrm{CE}_{\mathrm{f}}-\mathrm{CE}_{\mathrm{i}}\right) / \mathrm{CEI}$ Where $\mathrm{W}_{\mathrm{f}}$ its final body weight, $\mathrm{W}_{\mathrm{i}}$ is initial body weight, $\mathrm{t}$ is experimental duration in days, FI is dry feed intake $(\mathrm{g})$, $\mathrm{CPI}$ is crude protein intake $(\mathrm{g}), \mathrm{CP}_{\mathrm{i}}$ and $\mathrm{CP}_{\mathrm{f}}$ are estimates of crude protein content ( $\mathrm{g}$ ) of the biomass at the start and end of the experiment, $\mathrm{CE}_{\mathrm{i}}$ and $\mathrm{CE}_{\mathrm{f}}$ are estimates of energy content of the biomass at the start and end of the experiment and CEI is the crude energy intake.

Results are expressed as mean $\pm \mathrm{SD}$. All data were subjected to one-way ANOVA followed by the Tukey's test to determine significant differences among treatment groups and $\mathrm{P}<0.05$ was considered to be statistically significant. Protein requirements were estimated from body weight gain using the secondorder polynomial regression analysis model. From the regression, the optimal level supporting the maximum growth response was calculated. All statistical analyses were performed using Systat for Windows (v10.2, SPSS Inc., USA).

\section{RESULTS AND DISCUSSION}

Data on growth show that there was a gradual increment in WG $(46.5 \pm 5.0 \mathrm{~g})$ as dietary protein levels increased to $32 \%$ CP. Fish fed diet beyond $36 \%$ $\mathrm{CP}$ could not produce additional growth. There is some evidence that at very high feeding levels, protein deposition tends to level off (plateau) (BUREAU et al., 2002). Fish fed diets with lower CP levels showed reduced weight gain and efficiency of feed utilization. Dietary protein is the most important factor affecting growth performance of fish and feed cost. Generally, increasing protein level in diets can lead to improved fish production, especially for carnivorous fish. The demand of fish protein for growth is different according to species, feeding habits, physiological and development state, conditions of culture, sources of protein, dietary energy levels and the protein: energy ratio(ROBINSON \& LI, 1999; LUPATSCH et al., 2001). However, it has been determined that the average protein requirements in diets for growth of the mains fishes species cultivated in the world may oscillate between 31 and 55\% (NRC 1993) equivalents to 300700 parts kg-1 of GE content on diet in the protein form. Differences on WG in relation to the protein content in the diet, similar to those observed in this study, have been described for different species of fishes omnivorous such as jundiá Rhamdia quelen (MEYER \& FRACALOSSI, 2004), catfish Clarias gariepinus (ALI \& JANCEY, 2005) and Tilapia O. niloticus (ABDELTAWWAB et al., 2010). In this study the maximum WG in cachama juveniles was observed with $32 \%$ of dietary protein level. The influence of increased dietary protein levels on the growth response was examined by fitting dose-response data to a polynomial curve (Figure 1). The relationship between $W G$ and dietary protein level was described by the equation $\mathrm{Y}=-20.15+3.98 \mathrm{X}-0.063 \mathrm{X}^{2}$ $\left(\mathrm{R}^{2}=0.694\right)$. The optimal dietary protein level was determined to be $31.59 \%$ for maximum weight gain. This value is consistent with the results of GUTIERREZ et al. (1996) who determined that $29.8 \%$ of protein was necessary in practical growth diets for this species. Values obtained for fishes of the same family and similar feeding habitat, 26\% CP for pacu (FERNANDES et al., 2000) or 27\% (BICUDO et al., 2010) and for tambaqui, or 30\% (OISHI et al., 2010), were comparatively similar 


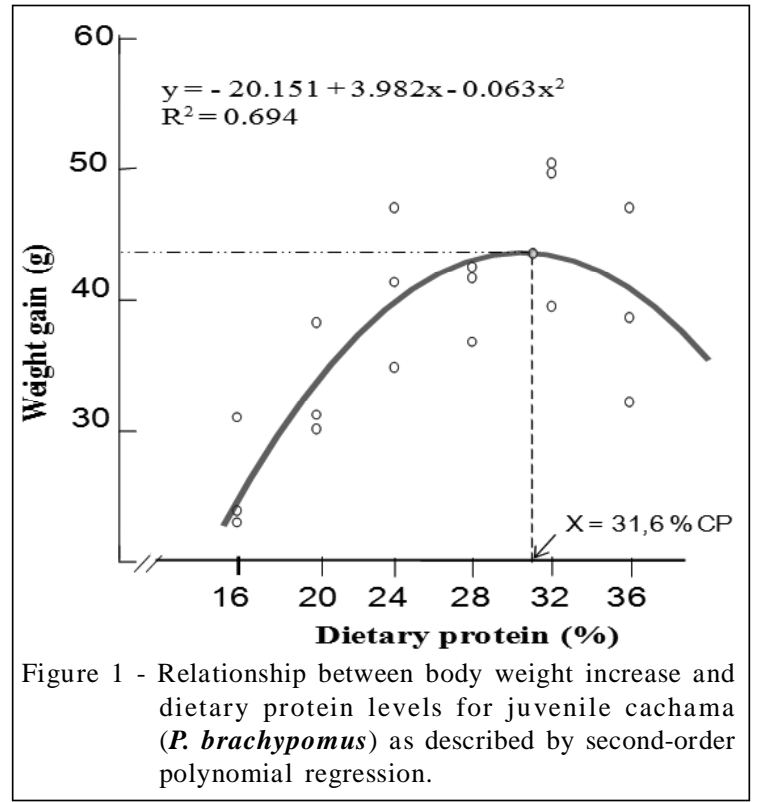

to those observed in this study. These values are also comparable with those of other omnivorous species such as catfish I. punctatus (ROBINSON \& LI, 1999), piracanjuba (SÁ \& FRACALOSSI, 2002), jundiá (MEYER \& FRACALOSSI, 2004; SALHI et al., 2004) and tilapia (ABDEL-TAWWAB \& AHMAD, 2009)

The highest SGR PER and bestFCR, were also observed in fish fed diet containing 32\% CP (Table 2). SGR varied significantly between 1.6 in fish fed with the diet with the lowest protein content up to 2.2 in those fed with the diet with $32 \%$ CP. Values of SGR obtained in this experiment for cachama juveniles fed with dietary protein levels above $20 \%$ (1.9 to 2.2), were higher than those observed for tambaqui (0.8-0.9) (OISHI et al., 2010), for pacu (0.75-0.81) (ABIMORAD \& CARNEIRO, 2007) and similar to those observed for this same species by FERNANDES et al. (2000); BICUDO et al. (2010). The increase of dietary protein to $36 \%$, above the optimum level determined in the present study, caused a significant decrease on WG and SGR in a similar way to that described for bagrid catfish Pseudobagrus fulvidraco (LEE \& LEE, 2005), jundia (MEYER \& FRACALOSSI, 2004) and bonitongue Heterotis niloticus (MONENTCHAN et al., 2010). According to DE SILVA \& ANDERSON (1995), this pattern in fish can be caused by an imbalance in the relationship protein/energy of diets when non proteic energetic sources diminish with a concomitant increase of protein contents. Such disproportion can shift the metabolic partition of protein towards the production of energy instead of protein synthesis. Since this is a frequently observed response in different fish species, it is suggested that in this experiment the diet with 36\% $\mathrm{CP}$, which was unbalanced in protein/energy ratio (37.4 $\mathrm{CP} / 12.7 \mathrm{kj} \mathrm{DE} \mathrm{kg}^{-1}$ ) due to protein excess, was one of the causes for growth depression of fish fed with it.

Feed intake was higher in fish fed with the lowest dietary protein level and gradually diminished in fish fed with $32 \%$ (Table 2). Low food consumption and high WG obtained in fish fed with $32 \% \mathrm{CP}$ produced a FCR of $1.1 \pm 0.03$, significantly better than that observed in fish fed with dietary protein levels above and below this level $(\mathrm{P}<0.05)$; differences in consumption due to dietary variations in $\mathrm{CP}$ levels similar to register in this experiment, were observed in tambaqui (VAN DER MEER et al., 1995) and jundia (SALHI et al., 2004). On the other hand, in pacu (FERNANDES et al., 2000) and catfish I. punctatus (ROBINSON \& LI, 1999), no significant influence of dietary protein levels on the consumption of dry matter were stated. The fishes, as well as terrestrial animals, eat to satisfy nutrients and energy demands. It is also

Table 2 - Growth response and feed utilization of juvenile Cachama (P. brachypomus) fed with diets containing graded levels of protein; Specific Growth Rate (SGR), Protein Efficiency Rate (PER), Dry Feed Intake (DFI), Feed Conversion Ratio (FCR). Protein Productive Value (PPV\%), Energy Productive Value (EPV\%) ${ }^{1}$.

\begin{tabular}{|c|c|c|c|c|c|c|c|}
\hline & \multicolumn{6}{|c|}{ 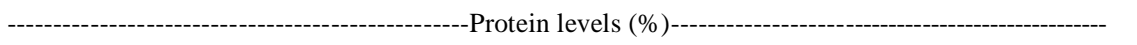 } & \multirow{2}{*}{$\mathrm{P}$} \\
\hline & 16 & 20 & 24 & 28 & 32 & 36 & \\
\hline WG $(\mathrm{g})$ & $26.0 \pm 3.56^{\mathrm{d}}$ & $33.2 \pm 3.58^{\mathrm{c}}$ & $41.1 \pm 4.92^{\mathrm{b}}$ & $40.3 \pm 2.46^{\mathrm{b}}$ & $46.5 \pm 5.01^{\mathrm{a}}$ & $39.3 \pm 6.05^{\mathrm{b}}$ & 0.009 \\
\hline SGR & $1.63 \pm 0.15^{\mathrm{d}}$ & $1.89 \pm 0.07^{\mathrm{c}}$ & $2.11 \pm 0.12^{\mathrm{ab}}$ & $2.11 \pm 0.06^{\mathrm{ab}}$ & $2.25 \pm 0.15^{\mathrm{a}}$ & $2.07 \pm 0.19^{\mathrm{b}}$ & 0.006 \\
\hline PER & $4.7 \pm 0.24^{\mathrm{a}}$ & $3.8 \pm 0.41^{\mathrm{b}}$ & $3.5 \pm 0.17^{\mathrm{bc}}$ & $3.2 \pm 0.04^{\mathrm{cd}}$ & $2.9 \pm 0.10^{\mathrm{d}}$ & $2.4 \pm 0.10^{\mathrm{e}}$ & 0.000 \\
\hline DFI & $1.51 \pm 0.02^{\mathrm{a}}$ & $1.40 \pm 0.05^{\mathrm{ab}}$ & $1.40 \pm 0.04^{\mathrm{ab}}$ & $1.32 \pm 0.01^{\mathrm{c}}$ & $1.32 \pm 0.06^{\mathrm{bc}}$ & $1.34 \pm 0.04^{\mathrm{bc}}$ & 0.005 \\
\hline FCR & $1.5 \pm 0.11^{\mathrm{a}}$ & $1.3 \pm 0.08^{\mathrm{b}}$ & $1.2 \pm 0.07^{\mathrm{bc}}$ & $1.2 \pm 0.03^{\mathrm{bc}}$ & $1.1 \pm 0.03^{\mathrm{c}}$ & $1.2 \pm 0.03^{\mathrm{bc}}$ & 0.000 \\
\hline $\operatorname{PPV}(\%)$ & $80.2 \pm 1.4^{\mathrm{a}}$ & $69.3 \pm 2.8^{\mathrm{b}}$ & $65.4 \pm 5.5^{\mathrm{b}}$ & $53.5 \pm 1.7^{\mathrm{c}}$ & $47.2 \pm 1.6^{\mathrm{cd}}$ & $38.9 \pm 2.7^{\mathrm{e}}$ & 0.000 \\
\hline $\operatorname{EPV}(\%)$ & $30.5 \pm 5.5$ & $35.8 \pm 3.0$ & $35.3 \pm 4.8$ & $34.7 \pm 0.6$ & $33.5 \pm 2.2$ & $33.0 \pm 0.8$ & 0.653 \\
\hline
\end{tabular}

\footnotetext{
${ }^{1}$ Data are means of triplicate \pm SD. Means in the same column sharing the different superscript letter are significantly different determined by Tukey test $(\mathrm{P}<0.05)$. Initial weight was $15.52 \pm 0.82 \mathrm{~g}$.
} 
believed that fish adjust food consumption to satisfy the metabolic energy requirements, however once minimum requirement are satisfied, the daily consumption may be related to dietary quality such as protein content (DE SILVA \& ANDERSON, 1995). In such cases, fish can adjust ingestion of food as a function of DE contents of the diet. In contrast, a diet containing excess energy can reduce feed consumption and thus lower the intake of the necessary amount of protein and other essential nutrient for maximum growth (NRC, 1993). In different species, it has been observed that when the diet is low in energy or in an essential nutrient for growth such as proteins, the animal compensates such deficiency by increasing its consumption (GUILLAUME et al., 2004). According to SANTINHA et al. (1999), when a fish is fed to satiety, weight gain will depend not only on the energy and nutrient content of the diet, also in its ability to regulate food intake. Consequently, these theories could explain the higher feed ingestion by $\boldsymbol{P}$. brachypomus fed diets isoenergetics with low protein. In agreement with the results of the present experiment (Table 2), GUTIERREZ et al. (1996) observed a decrease in the FCR value from 3.9 to 2.4 when $\boldsymbol{P}$. brachypomus were fed with increasing dietary protein levels from 27 to $30 \%$. A similar pattern was observed by FERNANDES et al. (2000) in pacu when dietary protein increased from 22 to $30 \%$ and also by SÁ \& FRACALOSSI (2002) in $\boldsymbol{B}$. orbignyanus fed with 24 to $36 \%$ CP. Values of FCR obtained in this study, between 1.3 and 1.1 for fish fed with dietary protein levels from 20 to $36 \%$, besides being in an average acceptable range for fishes (DE SILVA \& ANDERSON, 1995) and may be considered excellent when compared with those observed in experiments of close species as pacu (BECHARA et al., 2005) and tambaqui (OISHI et al., 2010). These values are also superior to those observed in other teleosts as $\boldsymbol{R}$. quelen (SALHI et al., 2004), tilapia (O. niloticus) (ABDEL-TAWWAB et al., 2010) and catfish
(ROBINSON \& LI, 1999). PER was negatively correlated with dietary protein levels and consequently the efficiency of the use of dietary protein for biomass gain was lower in fish fed with high protein levels. PER varied within a maximum value of 4.7 in fish fed with the lowest dietary protein level to 2.4 in those fed with the diet with the highest protein content PPV values, which showed that the amount of retained protein by fish had a similar behavior to that observed with PER and PPV were 2.9 and 47.2 respectively in fish fed with $32 \% \mathrm{CP}$, dietary protein level which led to maximum WG (Table 2). A negative relationship between dietary protein levels and PER and PPV was observed in pacu (BACHARA et al., 2005) and piracanjuba $\boldsymbol{B}$. orbignyanus (SÁ \& FRACALOSSI, 2002). Several studies demonstrated that high CP levels in the diet lead to lower PER and PPV values (MATHIS et al., 2003; LEE \& LEE, 2005). Apparently, this response is associated with the lack of digestible energy coming from non protein sources in the diets with the highest levels of CP inclusion. In order to keep the dietary energy constant, in this experiment lipid was used to regulate dietary energy, so lipid content in the diets decrease with increasing dietary protein level. Thus, in this study, the reason for the negative relationship between levels of dietary protein and PER, was that a greater amount of protein in the diets was used as an energy source. When fishes are fed with these diets, protein is then partially used as source of energy diminishing its possibilities of use for deposition in the tissues (FERNANDES et al., 2000; BICUDO et al., 2010). PPV in body significantly increased with increasing dietary protein levels from 16 to $20 \%$, but remained similar thereafter $(\mathrm{P}<0.05)$. At the end of the experiment the content of moisture, crude protein, lipid and gross energy in whole body were not significantly affected $(\mathrm{P}>0.05)$ (Table 3$)$. Similar results have been described by several researchers in studies with different species in the same experimental conditions,

Table 3 - Whole body proximate composition (\% on fresh/weight basis), gross energy and protein and energy efficiencies of juvenile cachama ( $\boldsymbol{P}$. brachypomus) fed diets containing different protein levels ${ }^{1}$.

\begin{tabular}{|c|c|c|c|c|c|c|c|}
\hline & \multicolumn{6}{|c|}{ 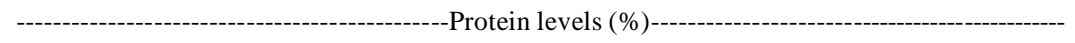 } & \multirow{2}{*}{$\mathrm{P}$} \\
\hline & 16 & 20 & 24 & 28 & 32 & 36 & \\
\hline Moisture & $67.8 \pm 0.51$ & $68.0 \pm 0.20$ & $68.2 \pm 2.79$ & $69.8 \pm 0.90$ & $70.9 \pm 1.13$ & $70.6 \pm 0.63$ & 0.051 \\
\hline Crude protein & $17.0 \pm 1.65$ & $19.9 \pm 0.41$ & $17.7 \pm 0.67$ & $16.3 \pm 0.31$ & $16.2 \pm 0.37$ & $16.1 \pm 0.74$ & 0.545 \\
\hline Ether Extract & $8.65 \pm 2.47$ & $11.57 \pm 0.88$ & $10.19 \pm 2.21$ & $10.10 \pm 0.76$ & $9.73 \pm 0.93$ & $9.72 \pm 0.74$ & 0.724 \\
\hline Ash & $3.22 \pm 0.59$ & $3.39 \pm 0.48$ & $3.21 \pm 0.45$ & $3.27 \pm 0.37$ & $3.24 \pm 0.23$ & $3.27 \pm 0.09$ & 0.998 \\
\hline $\mathrm{GE}\left(\mathrm{kcal} \mathrm{kg}^{-1}\right)$ & $6337 \pm 707$ & $6248 \pm 211$ & $6274 \pm 181$ & $6183 \pm 201$ & $6026 \pm 386$ & $6019 \pm 121$ & 0.836 \\
\hline
\end{tabular}

${ }^{1}$ Data are means of triplicate \pm SD. Means in the same column sharing different superscript letter are significantly different determined by Tukey test $(\mathrm{P}<0.05)$. 
WEBSTER et al. (2000) with catfish, SÁ \& FRACALOSSI (2002) with B. orbignyanus, MATHIS et al. (2003) with Perca fluviatilis, MEYER \& FRACALOSSI (2004) with $\boldsymbol{R}$. quelen and ABDELTAWWAB \& AHMAD (2010) with tilapia $\boldsymbol{O}$. niloticus.

\section{CONCLUSION}

It may be concluded that for $\boldsymbol{P}$. brachypomus juveniles a dietary protein level of $31.6 \% \mathrm{CP}$ is the optimum level for maximum growth and Feed Conversion Ratio. An increase on dietary protein level beyond 36\% seems to generate decrease on WG. The PER and PPV were negatively related with dietary protein levels.

\section{ACKNOWLEDGEMENTS}

This research was supported by the Instituto de Acuicultura de la Universidad de los Llanos and COLCIENCIAS (Colombia) and by Instituto Nacional de Pesquisas da Amazônia -INPA and CNPq (Brazil). The researchers thank Alvaro Wills (Laboratory ROCHE-Colombia) for supplying mixtures of minerals and vitamins used in this experiment.

\section{REFERENCES}

ABIMORAD, E.G.; CARNEIRO, D.J. Digestibility and performance of pacu (Piaractus mesopotamicus) juveniles fed diets containing different protein, lipid and carbohydrate levels. Aquaculture Nutrition, v.13, p.1-9, 2005.

ALI, M.Z.; JAUNCEY, K. Approached to optimizing dietary protein to energy ratio for African catfish Clarias gariepinus (Burchell 1822). Aquaculture Nutrition, v.11, p.95-101, 2005.

ARAUJO-LIMA, C.; GOULDING, M. So fruit a fish: ecology, conservation, and aquaculture of the Amazon's tambaqui. Biology and resource management in the tropic. New York: Columbia University, 1997. 191p.

BECHARA, J.A. et al. The effect of dietary protein level on pond water quality and feed utilization efficiency of pacu Piaractus mesopotamicus (Holmberg, 1887). Aquaculture Research, v.36, p.546-553, 2005.

BICUDO A.J.A. et al. Growth performance and body composition of pacu Piaractus mesopotamicus (Holmberg, 1887) in response to dietary protein and energy levels. Aquaculture Nutrition, v.16, p.213-222, 2010.

BUREAU D.P. et al. Bioenergetics. In: HALVER J.E.; HARDY R.W. Fish nutrition. San Diego: Academic, 2002. Cap.1. p.1-57.

DE SILVA, S.S.; ANDERSON, T.A. Fish nutrition in aquaculture. London: Chapman \& Hall, 1995. 319p.

FERNANDES, J.B.K. et al. Fontes e níveis de proteína bruta en dietas para alevinos de pacu (Piaractus mesopotamicus). Revista Brasileira de Zootecnia, v.29, n.3, p.646-653, 2000.
Available from: 〈http://www.scielo.br/pdf/rbz/v29n3/5805.pdf > Accessed: Aug. 8, 2011.

GUILLAUME J. et al. Nutrición y alimentación de peces y crustáceos. Madrid: Mundi-Prensa, 2004. 475p.

GUTIERREZ, W. et al. Determinación de los requerimientos de proteína y energía de juveniles de paco, Piaractus brachypomus. Folia Amazônica, v.8, p.35-45, 1996.

IBAMA. Bolletim estatístico da pesca e aquicultura, Brasil. 2008-2009. Brasília: Ministério da Pesca e Aquicultura, 2010. 99p. Available from: 〈http://200.198.202.145/>. Accessed: Apr. 26, 2011.

LEE, O.K.; LEE, S.-M. Effects of the dietary protein and lipid levels on growth and body composition of bagrid, Pseudobagrus fulvidraco. Aquaculture, v.243, p.323 -329, 2005.

LUPATSCH, I. et al. Effects of varying dietary protein and energy supply on growth, body composition and protein utilization in gilthead sea bream (Sparus aurata L.). Aquaculture Nutrition, v.7, p.71-80, 2001.

MADR. Pesca y acuicultura Colombia 2009. Bogotá D.C.: Ministerio de Agricultura y Desarrollo Rural, 2010. 70p. (Informe Técnico Regional Litoral Caribe y Pacífico). Available from: <http://201.234.78.28:8080/dspace/.../1/Informe\%202009Caribe-Pacifico.pdf $>$. Accessed: Apr. 25, 2011.

MATHIS, N. et al. Influence of protein-energy ratio on carcass quality during the growing period of Eurasian perch (Perca fluviatilis). Aquaculture, v.217, p.453-464, 2003.

MEYER, G.; FRACALOSSI, D.M. Protein requirements of jundiá fingerlings, Rhamdia quelen, at two dietary energy concentrations. Aquaculture, v.240, p.331-343, 2004.

MONENTCHAN, S.-E. et al. Influence of dietary protein on growth performance and body composition of African bonytongue fingelings Heterotis niloticus (Cuvier, 1829). Aquaculture Nutrition, v.16, p.144-152, 2010.

NATIONAL RESEARCH COUNCIL (NRC). Nutrients requirements of fish. Washington. D.C., 1993. $115 \mathrm{p}$.

OISHI C.A. et al. Optimum dietary protein requirement for Amazonian Tambaqui Colossoma macropomum, fed fish meal free diets. Acta Amazónica, v.40, n.4, p.757-762, 2010.

ROBINSON, E.H.; Li, M.H. Effect of dietary protein concentration and feeding rate on weight gain, efficiency, and body composition of pond-raised channel catfish Ictalarus punctatus. Journal of the Word Aquaculture Society, v.30, p.311-318, 1999.

SÁ, M.V.; FRACALOSSI, D.M. Dietary protein requirement and energy to protein ratio for Piracanjuba (Brycon orbignyanus). Revista Brasileira de Zootecnia, v.31, n.1, p.1-10, 2002. Available from: <http://www.scielo.br/pdf/rbz/ v31n1/8942.pdf>. Accessed: Aug. 8, 2011.

SALHI, M. et al. Growth, feed utilization and body composition of Rhamdia quelen, fry fed diets containing different protein and energy levels. Aquaculture, v.231, p.435-444, 2004. 
SANTINHA, P.J.M. et al. Effects of the dietary protein: lipids ratio on growth and nutrient utilization in seabream (Spaurus aurata). Aquaculture Nutrition, v.5, p.147-156, 1999.

THOMAN, E.S. et al. Evaluation of growth diets with varying protein and energy levels for red drum (Sciaenops ocellatus). Aquaculture, v.176, p.343-353, 1999.

VAN DER MEER, M.B. et al. The effect of dietary protein level on growth, protein utilization and body composition of C. macropomum (Cuvier). Aquaculture Research, v.26, p.901-909, 1995.

VÁSQUEZ-TORRES, W. et al. Studies for composition of semi purified reference diet for nutritional requirements evaluation of juvenile pirapitinga Piaractus brachypomus (Cuvier, 1818). Revista Brasileira de Zootecnia, v.31, p.283-292, 2002. Available from: <http://www.scielo.br/pdf/ rbz/v31n1s0/10307.pdf>. Accessed: Aug. 8, 2011

WEBB, K.A. JR.; GATLIN III, D.M. Effects of dietary protein level and form on production characteristics and ammonia excretion of red drum Sciaenops ocellatus. Aquaculture, v.225, p.17-26, 2003.

WEBSTER, C.D. et al. Differences in growth in blue catfish Ictalarus furcatus and channel fish I. punctatus fed low-protein diets with and without supplemental methionine and /or lysine. Journal of the Word Aquaculture Society, v.31, p.195205, 2000.

WILSON, R.R. Amino acid and proteins. In: HALVER J.E.; HARDY R.W. Fish nutrition. San Diego: Academic, 2002. p.143-179. 